\title{
Pensononowoor
}

2021, vol. 85, 51-59

https://doi.org/10.12657/denbio.085.006

\author{
Soon-Ho Kwon, Yang-Gil Kim, Hye-In Kang, Donghwan Shim, \\ Kyu-Suk Kang*
}

\section{Morphology of strobili at different development positions and cone and seed characteristics of Pinus densiflora f. multicaulis}

Received: 31 October 2020; Accepted: 19 February 2021

\begin{abstract}
Pinus densiflora f. multicaulis is a rare and unusual form of genus Pinus. It has excellent ornamental values due to many trunks from its root collar, and produces female, male, and bisexual strobili on the same tree. However, there is limited study whether the bisexual strobili are functional, mature lateral cones produce filled seeds, and the seeds from the mature lateral cones germinate and grow as well as those from mature apical cones. The structure of apical female, and lateral male and bisexual strobili were analyzed in an open-pollination-progeny population. The strobili were photographed to obtain external, cross-section, and radial-section images using a $45 \times$ stereoscopic microscope. Radial sections of strobili were imaged using scanning electron microscopy. Characteristics of apical and lateral cones and seeds were surveyed by cone analysis and germination test. P. densiflora f. multicaulis developed typical female strobili apically, and ordinary male and bisexual strobili laterally. Additionally, female strobili developed laterally whereas the male strobili were normally located. The mature lateral female strobili had the same structure as the apical female. In the mature bisexual strobili, the proportion of male and female tissue was unequal. The cones developed from lateral female strobili showed highly significant differences in the length, width, and weight, being shorter $(32.7 \%)$, narrower $(26.9 \%)$, and lighter $(59.8 \%)$ than those from apical female strobili. Both types produced filled seeds and seedlings, and well significant positive correlations were found among characteristics of seeds from apical and lateral female strobili. The initial seed germination rate of the seeds from apical female strobili was higher than that of seeds from lateral female strobili, but the difference decreased over time. The viability and spatial distribution of the female and male tissue of bisporangiate cones, and their frequent occurrence suggests a common mechanism for the production of bisporangiate structures in seed plants.
\end{abstract}

Keywords: bisexual strobili, sex reversal, microsporangia, megasporangia, cone analysis

Addresses: S. H. Kwon, H. Kang, Department of Forest Genetic Resources, National Institute of Forest Science, Suwon 16631, Republic of Korea, e-mail: shkwon84@korea.kr; emmahi@snu.ac.kr; (1) S-HK https://orcid.org/0000-0003-4142-9973, (1) H-IK https://orcid.org/0000-0001-7495-7356 Y. G. Kim, K. S. Kang, Department of Agriculture, Forestry and Bioresources, College of Agriculture and Life Sciences, Seoul National University, 1 Gwanak-ro, Gwanak-gu, Seoul 08826, Republic of Korea, e-mail: rladidrlf@snu.ac.kr; kangks84@snu.ac.kr; (1) Y-GK https://orcid.org/0000-0001-8706-205X, (1) K-SK https://orcid.org/0000-0002-2368-5423

D. Shim, Department of Biological Sciences, Chungnam National University, Daejeon 34134, Republic of Korea, e-mail: shim.donghwan@gmail.com; (1) https://orcid.org/0000-0002-0223-595X *Corresponding author 


\section{Introduction}

Conifers, as with most gymnosperms, are monoecious that produce both microsporangia and megasporangia, which give rise to male and female gametophytes, respectively (Flores-Renteria et al., 2011, 2013). In contrast, mosses, liverworts, and hornworts are homosporous, which produce one sporangium from an unbranched sporophyte. Conifers typically bear microsporangia on microsporophylls aggregated into pollen strobili, and the ovules are located at modified stem axes forming compound ovuliferous cone scales (Kang, 2007).

Species in the Pinaceae lack the basic floral structure found in angiosperms. The male flower of Pinaceae is called the male strobilus (staminate strobilus); the female flower is called the female strobilus (ovulate strobilus). Although they are incomplete, these flowers produce reproductive cells with determinate growth (Jackson \& Sweet, 1972). It is generally known that female and male strobili develop at different locations-females develop apically, and males develop laterally-on branches. Additionally, the proportions of male and female strobili on a tree are determined by the size, age and abiotic situation of the branches.

Some cases was reported in Pinaceae which have bisexual strobili, the female and male strobili become joined at the position where the male strobili develop (Rao, 1931; Rao, 1932; Righter, 1932; Santamour, 1959; Ross et al., 1987) based on morphological research (Caron \& Powell, 1990; Wakushima et al., 1997; Osborne \& Gorelick, 2002; Flores-Rentería et al., 2011) and pollen viability study (Zobel, 1952; Caron \& Powell, 1995).

Pinus densiflora f. multicaulis is a rare and unusual form of genus Pinus that is distributed mainly on the Korean peninsula and in Japan (Hwang \& Lee, 1996). Unlike other pine species, it does not develop a straight stem, and branches at the root collar into several trunks. It is shorter than other Pinus species (Woo, 2003), and has excellent ornamental values. It is often propagated by grafting, for commercial or research purposes (Moon, 2010). It has been shown to have significant phenotypic differences from $P$. densiflora (Woo, 2003). Further, it differs in karyotype from $P$. densiflora, and has specific and intrinsic isotope bands (Kim et al., 1990) and chloroplast DNA sequences (Kang, 2007). Studies on the development of strobili in pine species have reported that photosynthesis, carbohydrate content, inorganic nutrition, and phytohormones affect the occurrence and rate of female and male strobili, and the transition from male to female strobili (Wareing, 1958; Sarvas, 1962; Silen, 1973). On the other hand, there is limited study whether these bisexual strobili are functional, whether mature lateral cones produce filled seeds in the same way as mature apical cones, and whether the seeds from the mature lateral cones germinate and grow as well as those from mature apical cones in P. densiflora f. multicaulis.

Until the 2010s, research on the development of the reproductive organs of gymnosperm, to which Pinaceae belongs, was insufficient, but recently, studies are being conducted using genomic information tools (Niu et al., 2016). The interpretation of the results of the latest genetic studies can be clarified through a detailed morphological observation of the reproductive organ development of gymnosperm.

The objectives of this study were: 1 ) to survey the developmental differences of apical and lateral strobili; 2) to assess the viability of seeds from female lateral and bisexual strobili; and 3) to compare the germination speed, and percentage from female apical strobili (i.e., mature apical cone seeds), and from bisexual and female lateral strobili (mature lateral cone seeds).

\section{Material and methods}

\section{Plant materials and strobilus survey}

The observations of female, male, and bisexual strobili of Pinus densiflora f. multicaulis were conducted in an open-pollination-progeny population, which was established in Hwacheon-gun, Gangwon-do (38 $\left.16^{\prime} 59^{\prime \prime} \mathrm{N}, 127^{\circ} 66^{\prime} 06^{\prime \prime} \mathrm{E}, 181 \mathrm{~m}\right)$, in northern South Korea. Trees were grown from seeds that had been collected from selected mothers. The progeny showing the typical $P$. densiflora f. multicaulis phenotype were sampled when 18 years old in 2019.

Photographs of strobili attached to the trees were taken using a digital camera and telephoto macro lens (Sony ${ }^{\mathrm{TM}}$ ILCE-9 and SEL90M28G, Japan). The collected strobili were photographed to obtain external, cross-section, and radial-section images of strobili using a $45 \times$ stereoscopic microscope (Olympus $^{\mathrm{TM}}$ SZ61, Japan). The bisexual strobilus samples were coated with platinum (Leica ${ }^{\mathrm{TM}}$ EM ACE200 sputter coater, Germany) after pretreatment. The samples were tandemly pretreated to ethanol $25 \%$ for 30 minutes, $50 \%$ for 30 minutes, $75 \%$ for 30 minutes and finally $100 \%$ for 1 hour. Radial sections and pollen in strobili were then imaged using scanning electron microscopy (Sigma ${ }^{\mathrm{TM}} 300$ VP-FESEM, Japan).

\section{Cone analysis and germination test}

Mature seed-cones were collected from four individuals that were selected from natural stands, grafted, and planted at the experimental forest of the Seoul National University, Gwanak-gu, Seoul, 
South Korea. They were 15 years old, without any damage. For each of mature apical and lateral cone, the length, width, and weight were measured, and the total number of scales and the number of fertile scales were calculated; these data were then analyzed using the cone analysis method (Bramlett et al., 1977). Aborted ovules were divided into first-year and second-year aborted ovules. Seeds were divided into filled seeds and empty seeds. The characteristics of cones and seeds were analyzed using Pearson's correlation analysis and the Student's t-test in R ( R Core Team R Foundation, 2012).

Seeds were then obtained from mature apical and lateral cones. The collected seeds were sterilized using alcohol, placed on a piece of filter-paper inside a petri dish, and wet with sterile water. The seeds were then kept at constant temperature $\left(25^{\circ} \mathrm{C}\right)$ and humidity $(60 \%)$ for the germination test. The photoperiod comprised a 16-h light / 8-h dark cycle, for the four-week germination period in the growth chamber.

\section{Results}

\section{Morphological characteristics of female, male and bisexual strobili}

Pinus densiflora f. multicaulis developed typical female strobili apically, and ordinary male and bisexual strobili laterally, on one-year-old branches (i.e., twigs). Additionally, we found that female strobili developed laterally whereas the male strobili were normally located (Figs 1 and 2). We referred to these as lateral female strobili.

The frequency and location of lateral female and bisexual strobili varied among individuals. Within individuals, these strobili developed at the same locations each year, and new strobili developed randomly from branch to branch. The proportions of female to male tissue within lateral female bisexual strobili were not constant among branches or between individuals.

Male strobili did not have a pedicel on a new branch, but developed directly from the branch (Fig.
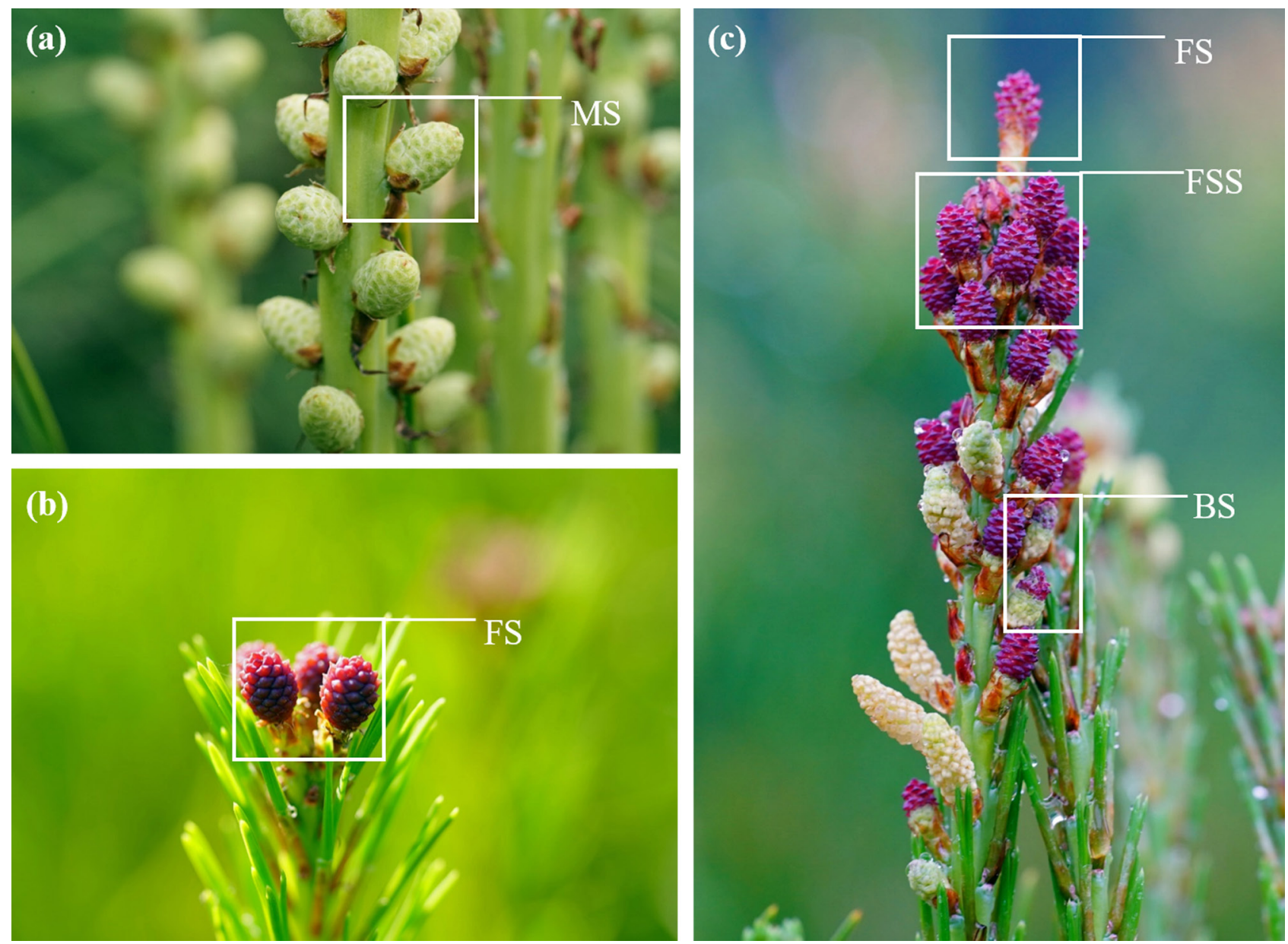

Fig. 1. Classification of the types of Pinus densiflora f. multicaulis strobili: (a) Ordinary male strobili at the lateral position of
a new branch (MS); (b) Typical female strobili at the apical position (FS); (c) Shoot with female strobili at the apical (FS) and lateral positions (FSS), and bisexual strobili (BS) 


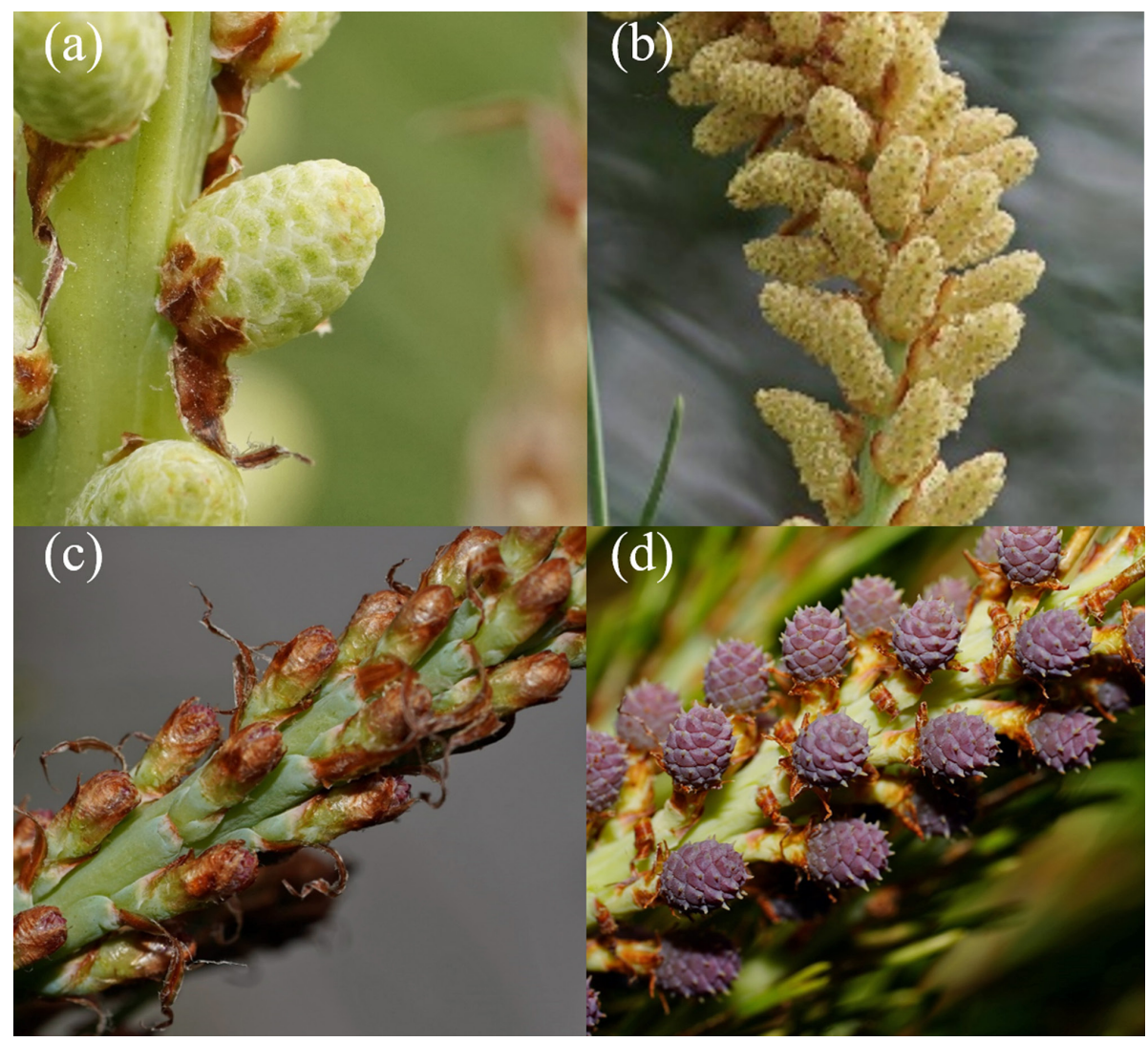

Fig. 2. Images of (a) immature Pinus densiflora f. multicaulis male strobili (MS), (b) pollen-releasing male strobili, (c) immature female strobili at the lateral position (FSS), and (d) pollinated mature female strobili at the lateral position

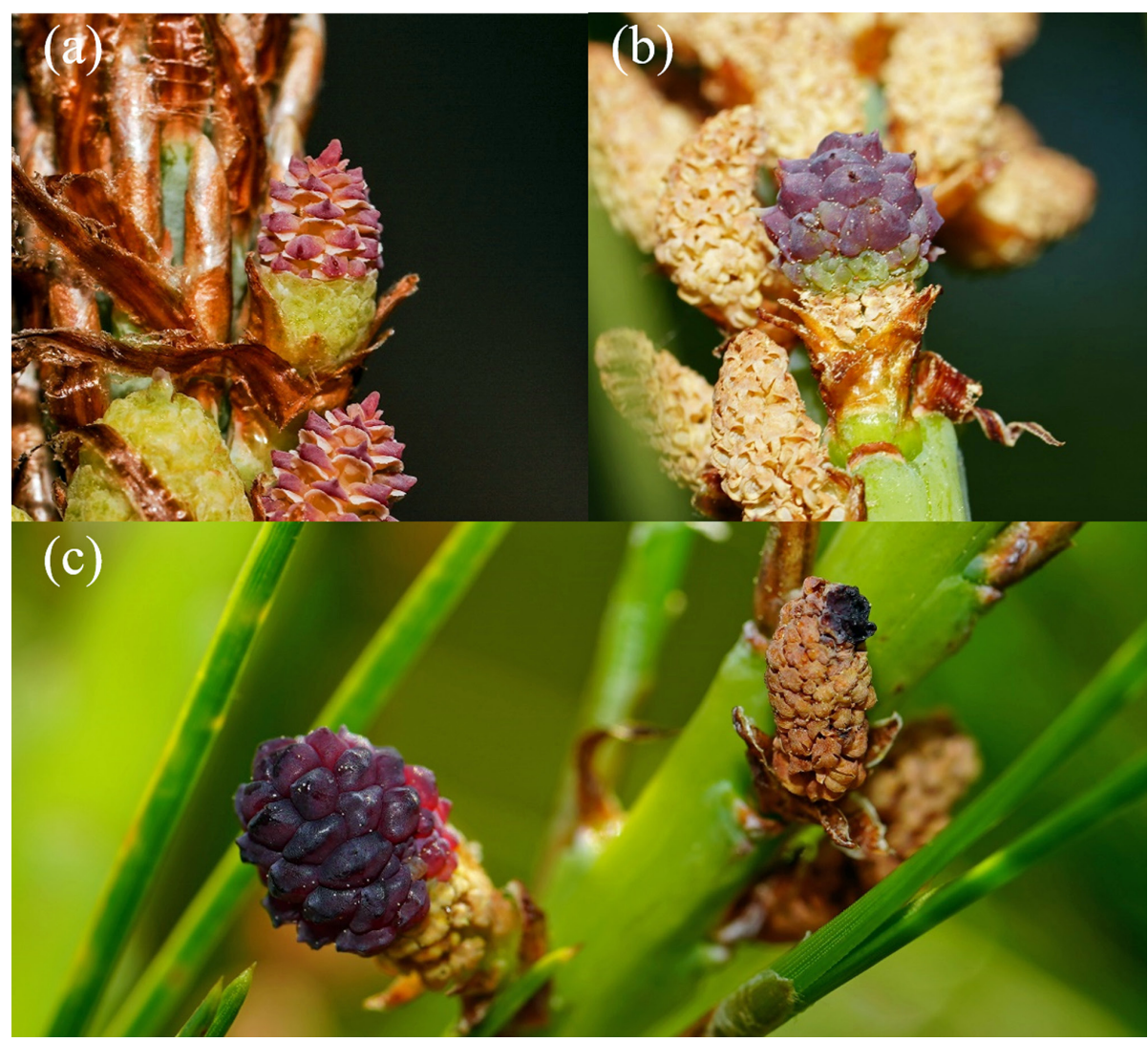

Fig. 3. Images of (a) immature bisexual strobili (BS), (b) premature bisexual strobili, and (c) mature (left) and undeveloped bisexual strobili (right) in Pinus densiflora f. multicaulis 
(a)

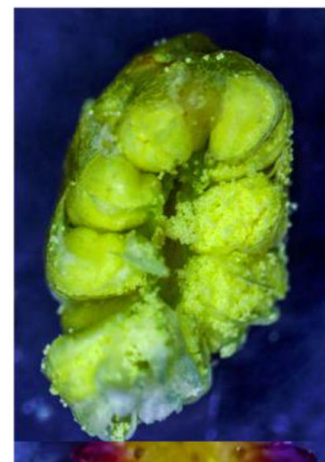

(b)

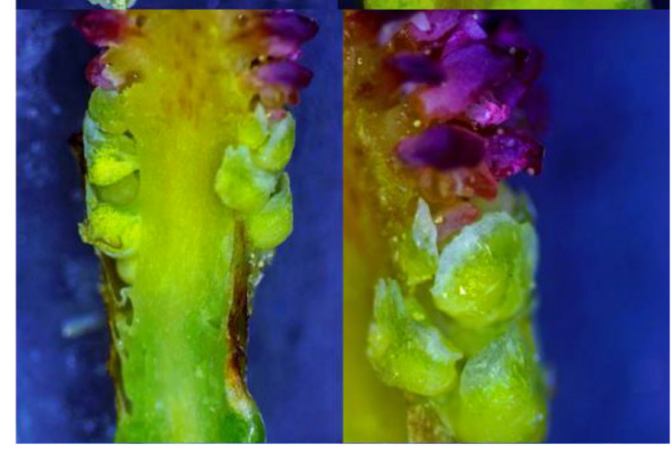

(c)

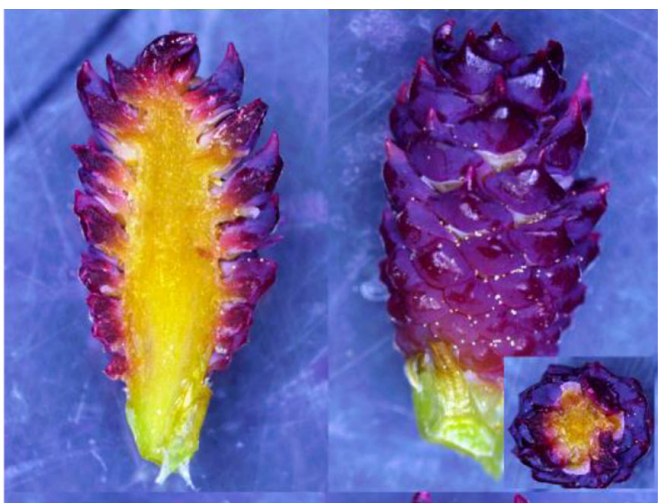

(d)

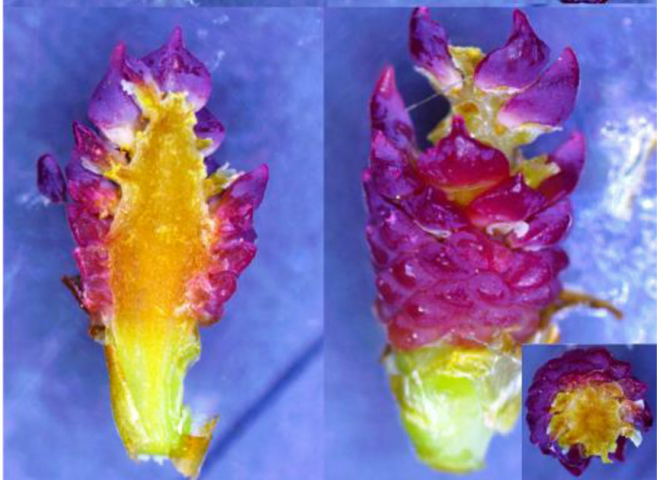

Fig. 4. Longitudinal section images of (a) male strobili (MS), (b) bisexual strobili (BS), and female strobili at (c) the lateral (FSS) and (d) the apical position (FS) under dissection microscope in Pinus densiflora f. multicaulis

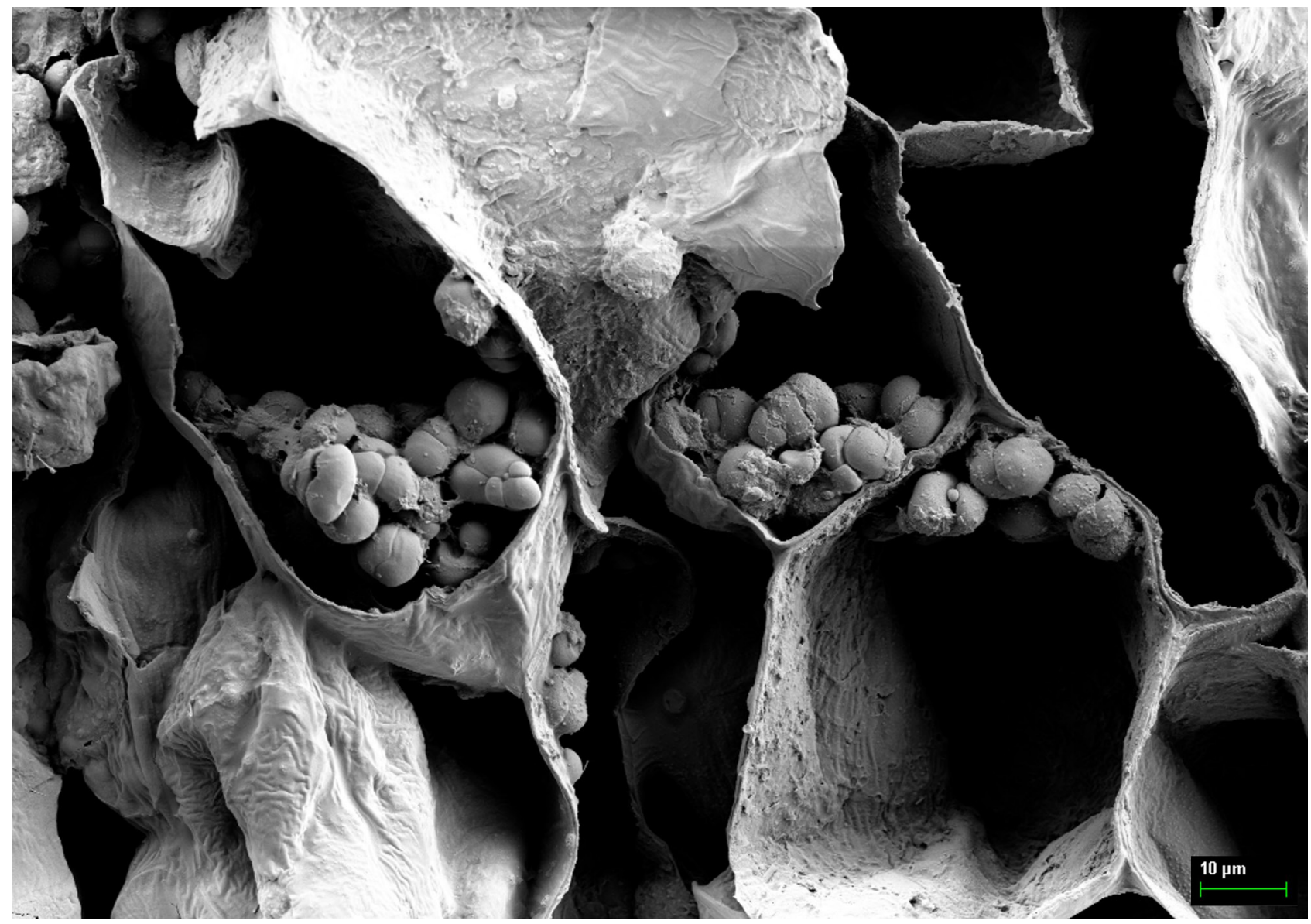

Fig. 5. Mature pollen grains in the pollen sacs of the bisexual strobili of Pinus densiflora f. multicaulis, by scanning electron microscopy (2000X) 
2a). The male strobilus consisted of numerous pollen sacs containing pollen grains and moisture. When the pollen grains reached maturity, the pollen sac exploded and increased in length, thus causing pollen to leave the pollen sacs and be blown away by the wind (Fig. 2b). Unlike the development of the male strobilus, the pedicels of lateral female strobili developed from an early stage, on the one-year-old branches, as they did for female apical strobili (Fig. 2c). Bisexual strobili also developed pedicels from an early stage of development.

The mature lateral female strobili had the same structure and shape as the apical female strobili (Fig. $2 \mathrm{~d})$. In the mature bisexual strobili, the proportions of male and female tissue were unequal (Fig. 3). Bisexual strobili with more female than male tissue had more highly developed pedicels; more male tissue was associated with smaller pedicels (or no pedicels). When the bisexual strobili developed no pedicel, they did not develop a cone. When more than half of the strobilus comprised female tissue, the bisexual strobilus developed into conelets (immature seedcones). Even when a small proportion of male tissue had formed in the lower part of a bisexual strobilus, it was possible to blow pollen out of it; such strobili dropped from the branch after pollination (Fig. 3).

Pollen matured in the male tissue of bisexual strobili, regardless of the proportion of the male tissue, and pollinated the apical or lateral female strobili.
When more than half of the bisexual strobilus comprised female tissue, the strobilus developed into a mature cone. The cross-section image confirmed that the pollen sac of the bisexual strobilus was opened, and that pollen was blown away (Fig. 4a and 4b), as for the male strobilus pollen sac (Fig. 5).

\section{Characteristic of mature apical and lateral cones and seed germination}

In total, 57 mature apical cones, with no sexual reversal, were harvested, and 37 mature lateral cones were harvested. Cone analysis was conducted to evaluate the statistical differences in morphological traits between the mature apical and lateral cones. On average, each individual produced 9.25 lateral seed-cones. The average length, width, and weight were all higher for mature apical cones than for mature lateral cones (Table 1); on average, the mature apical cones were $148.7 \%$ longer, $136.9 \%$ wider, and $248.6 \%$ heavier than the lateral cones. For the mature apical cones, the coefficients of variation were $16 \%$ for length, $18 \%$ for width, and $43 \%$ for weight (Table 1); those of the mature lateral cones were relatively larger (23\% for length, $22 \%$ for width, and $63 \%$ for weight), thereby implying greater variability in the characteristics of mature lateral cones than mature apical cones.

Table 1. Average of the Pinus densiflora f. multicaulis cone morphological characters (length, width, and weight), number of scales, fertile seeds, filled seeds, and empty seeds, and first- and second-year aborted ovules, based on analysis of cones collected from the apical (CA) and the side (CS) positions on the branch

\begin{tabular}{|c|c|c|c|c|c|c|c|c|c|}
\hline & \multicolumn{3}{|c|}{ Cone morphology } & \multirow{2}{*}{ No. of scales } & \multirow{2}{*}{$\begin{array}{l}\text { No. of fer- } \\
\text { tile seeds }\end{array}$} & \multirow{2}{*}{$\begin{array}{c}\text { No. of filled } \\
\text { seeds }\end{array}$} & \multirow{2}{*}{$\begin{array}{l}\text { No. of emp- } \\
\text { ty seeds }\end{array}$} & \multicolumn{2}{|c|}{ Aborted ovules } \\
\hline & length $(\mathrm{mm})$ & width $(\mathrm{mm})$ & weight $(\mathrm{g})$ & & & & & first-year & second-year \\
\hline $\mathrm{CA}$ & $30.72(1.45) \dagger$ & $17.93(0.81)$ & $5.47(0.69)$ & $60.87(4.00)$ & $25.94(2.53)$ & $3.55(1.32)$ & $10.45(3.93)$ & $34.28(4.51)$ & $3.60(0.65)$ \\
\hline CS & $20.66(1.56)$ & $13.10(0.95)$ & $2.20(0.46)$ & $63.49(3.77)$ & $7.87(4.26)$ & $0.43(0.37)$ & $5.38(2.99)$ & $8.89(5.02)$ & $0.92(0.73)$ \\
\hline $\mathrm{T}$ & 9.469 & 7.741 & 7.860 & -0.951 & 7.297 & 4.555 & 2.050 & 7.520 & 5.468 \\
\hline $\mathrm{p}$ & $* * *$ & $* * *$ & $* * *$ & ns & $* * *$ & $* * *$ & $* *$ & $* * *$ & $* * *$ \\
\hline
\end{tabular}

$\dagger$ Standard devisation in parenthesis; $T, t$-value; ns, non-significant; ${ }^{* *}$ and ${ }^{* * *}, p<0.01$ and $p<0.001$, respectively.

Table 2. Correlation coefficient of the characteristics of cones from the apical position (CA) (above the diagonal) and side position (CS) of the branch (below the diagonal) in Pinus densiflora f. multicaulis

\begin{tabular}{|c|c|c|c|c|c|c|c|c|c|}
\hline CA & $\begin{array}{l}\text { Cone } \\
\text { length }\end{array}$ & $\begin{array}{l}\text { Cone } \\
\text { width }\end{array}$ & $\begin{array}{c}\text { Cone } \\
\text { weight }\end{array}$ & $\begin{array}{l}\text { No. of } \\
\text { scales }\end{array}$ & $\begin{array}{l}\text { No. of fer- } \\
\text { tile scales }\end{array}$ & $\begin{array}{c}\text { First-year } \\
\text { aborted ovules }\end{array}$ & $\begin{array}{c}\text { Second-year } \\
\text { aborted ovules }\end{array}$ & $\begin{array}{l}\text { Empty } \\
\text { seeds }\end{array}$ & $\begin{array}{l}\text { Filled } \\
\text { seeds }\end{array}$ \\
\hline Cone length (mm) & - & $0.946^{* * *}$ & $0.978^{* * *}$ & $0.830^{* * *}$ & $0.757^{* * *}$ & 0.016 & 0.124 & $0.680^{* * *}$ & $0.757^{* * *}$ \\
\hline Cone width (mm) & $0.973^{* * *}$ & - & $0.964 * * *$ & $0.895^{* * *}$ & $0.780 * * *$ & -0.014 & 0.037 & $0.750 * * *$ & $0.782 * * *$ \\
\hline Cone weight (g) & $0.975^{* * *}$ & $0.978^{* * *}$ & - & $0.861^{* * *}$ & $0.781^{* * *}$ & 0.074 & 0.141 & $0.649 * * *$ & $0.732 * * *$ \\
\hline No. of scales & $0.649 * * *$ & $0.729 * * *$ & $0.673^{* * *}$ & - & $0.845^{* * *}$ & 0.138 & -0.109 & $0.694 * * *$ & $0.750 * * *$ \\
\hline No. of fertile scales & $0.847^{* * *}$ & $0.851^{* * *}$ & $0.919 * * *$ & $0.558^{* * *}$ & - & $0.480^{* * *}$ & 0.131 & $0.517^{* * *}$ & $0.583^{* * *}$ \\
\hline $\begin{array}{l}\text { First-year aborted } \\
\text { ovules }\end{array}$ & $0.825^{* * *}$ & $0.822^{* * *}$ & $0.894^{* * *}$ & $0.556^{* * *}$ & $0.978^{* * *}$ & - & $0.410^{* *}$ & $-0.485^{* * *}$ & $-0.341^{*}$ \\
\hline $\begin{array}{l}\text { Second-year aborted } \\
\text { ovules }\end{array}$ & $0.602^{* * *}$ & $0.616^{* * *}$ & $0.610^{* * *}$ & 0.292 & $0.615^{* * *}$ & $0.533^{* * *}$ & - & $-0.379^{* *}$ & -0.271 \\
\hline Empty seeds & $0.776^{* * *}$ & $0.791^{* * *}$ & $0.859^{* * *}$ & $0.518^{* * *}$ & $0.939 * * *$ & $0.863^{* * *}$ & $0.563^{* * *}$ & - & $0.850 * * *$ \\
\hline Filled seeds & $0.646^{* * *}$ & $0.638^{* * *}$ & $0.681^{* * *}$ & $0.446^{* *}$ & $0.711^{* * *}$ & $0.744^{* * *}$ & 0.272 & $0.536^{* * *}$ & - \\
\hline
\end{tabular}

$*, * *$, and ${ }^{* * *}, \mathrm{p}<0.05, \mathrm{p}<0.01$, and $\mathrm{p}<0.001$, respectively. 
The numbers of scales did not differ significantly between the mature apical (mean: 60.87) and lateral cones (mean: 63.49) (Table 1). However, the mean number of fertile seeds was much higher in mature apical (25.94) than in lateral cones (7.87). Similarly, the mean number of filled seeds was much higher in mature apical (3.55) than in lateral cones (0.43). The average numbers of empty seeds and aborted ovules showed the same trends (Table 1), thereby implying that the mature lateral cones showed less ability to produce viable seeds.

For the analysis of mature apical cones, Pearson's correlation coefficients among cone length, width, weight, and the total numbers of scales, fertile scales, empty seeds, and filled seeds, were all highly significant and positive (Table 2). However, the numbers of first- and second-year aborted ovules did not correlate

Table 3. Germination rate and sprout growth of Pinus densiflora f. multicaulis seeds collected from the apical position (CA) and the side position (CS) of the branch

\begin{tabular}{lccc}
\hline \multirow{2}{*}{ Position type } & \multicolumn{2}{c}{ Germination (\%) } & $\begin{array}{c}\text { Sprout growth } \\
\text { (cm) }\end{array}$ \\
\cline { 2 - 3 } & After 1 week & After 4 weeks & 3.4 \\
CA & 20.3 & 30.5 & 1.5 \\
CS & 7.5 & 28.3 & $* *$ \\
$\mathrm{p}$ & $* *$ & ns & $*$ \\
\hline
\end{tabular}

**, $\mathrm{p}<0.01, \mathrm{~ns}$, non-significant (t-test).
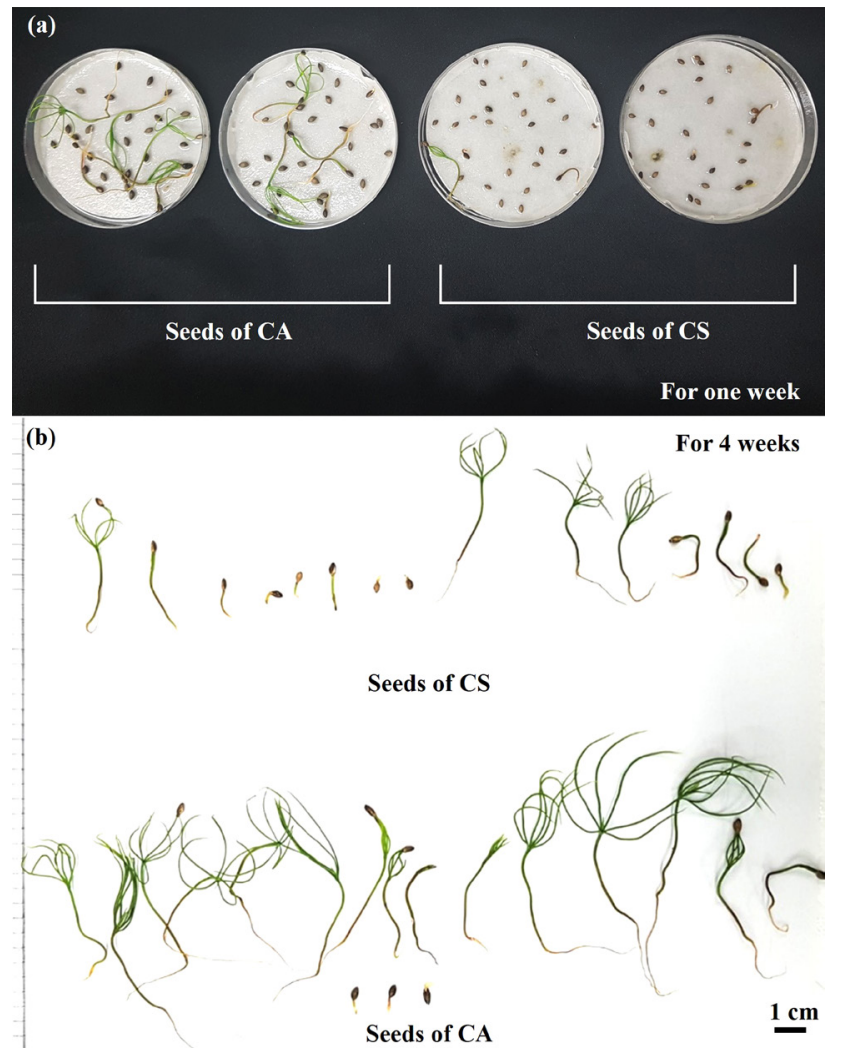

Fig. 6. Germination and growth of sprouts from Pinus densiflora f. multicaulis seeds obtained from the apical position (CA) and the side position (CS): (a) after one week and (b) after 4 weeks with the other cone characteristics, except with the number of fertile scales. For the analysis of lateral cones, the correlation coefficients were positive and significant among most cone traits; the correlations between the number of second-year aborted ovules, the total number of scales, and the number of filled seeds were not significant (Table 2)

We obtained 59 seeds from the mature apical cones, and 53 from mature lateral cones, and tested their germination. After one week, $20.3 \%$ of the apical cone seeds, and $7.5 \%$ of the lateral cone seeds, had germinated (Table 3, Fig. 6). After four weeks, however, the difference in the germination rate had dropped, with germination rates of $30.5 \%$ (apical cones) and $28.3 \%$ (lateral cones). The average lengths of the sprouts differed significantly, at $3.4 \mathrm{~cm}$ (apical cones) and $1.5 \mathrm{~cm}$ (lateral cones) (Table 3).

\section{Discussion}

\section{Morphological characteristics of strobili}

Conifer strobili typically have unisexual structures: pollen-producing (microsporangiate or male) and ovule-producing (megasporangiate or female) structures. The cones of Pinus species consist of a female strobilus (seed cone), male strobilus (male cones) and bisexual strobilus (Bartlett, 1913; Black, 1961; Caron \& Powell, 1990). Until recently, most studies have documented normal female strobilus, normal male strobilus, and bisexual strobilus (Feng et al., 2018). Here, we report, for the first time, the presence of lateral female strobili, with the same structure and function as the typical apical female strobili. Feng et al. (2018) presented only transformation strobili from male to female. But, we would like to inform you that it is a female strobilus that develops in a complete form from the beginning. Based on structure and position, we identified four types: apical and lateral female strobili, and lateral male and bisexual strobili. The lateral female strobili developed cones and produced filled seeds that germinated normally.

Abnormal seed-cones, sexual reversal of microsporangiate cones to polycones, have long been known in many coniferous families (particularly in the Pinaceae), from trees growing in botanical gardens and in natural populations (Bartlett, 1913; Black, 1961; Ross \& Pharis, 1987; Caron \& Powell, 1990; Matziris, 2002; Kang, 2007; Flores-Rentería et al., 2011; Feng et al., 2018). However, no previous studies have examined the possibility of seed production and germination from polycones. We confirmed that the male and female tissues of bisexual strobili developed and participated in pollination and fertilization when the female tissue comprised more than half of the bisexual strobilus. 
There have been a few studies of the mechanisms of sexual reversal of the unisexual flowers of gymnosperms. For Picea mariana, Caron and Powell (1990) reported that bisporangiate strobili were borne only when the tree first initiated reproductive activity, at an early age, and mostly on shoots near the megasporangiate zone. This is consistent with our results for P. densiflora f. multicaulis. However, in our study, the bisexual and lateral female strobili occurred separately in the lateral (microsporangiate) zone, and they produced cones and seeds in almost every year of the study.

\section{Comparison of cone and seed characteristics between apical and lateral positions}

The morphological characteristics of the apical cones and seeds were significantly superior to those of the lateral cones and seeds; their final germination rate was similar, but after four weeks, the length of apical sprouts was 2.3 times greater than that of lateral sprouts. The fact that the lateral cone and seed traits were inferior to the apical traits could be due to inbreeding depression, differences in energy allocation, and sexual interference. In the first case, lateral female and bisexual strobili might have a relatively high chance of self-pollination, compared to the apical strobili. Second, due to the trade-offs involved in sex allocation, ovule and pollen maturity may not be properly achieved with the relocated, limited energy. Third, there may be limited physical space for ovary development, causing interference with pollen-generation, thereby self-inhibiting seed maturation. Kim et al. (1989) reported that, compared with P. densiflo$r a, P$. densiflora f. multicaulis had poorer germination in the nursery, and produced smaller two-year-old seedlings. Similar results have been reported for a dioecious species, Jacaratia mexicana, in which the germination rate of seeds from a male tree was less than a third than that of seeds from a female tree (Aguirre et al., 2007). In addition, as the difference in germination rate of seeds obtained from CA and CS decreases over time, it is estimated that the characteristics of each seed do not affect the germination rate, but affect the time it takes to germinate. There are studies showing that depending on the species, the size and characteristics of seeds show a different correlation with the germination pattern (Figuerola et al., 2010). In P. densiflora f. multicaulis, seed size and germination time seem to have a positive correlation.

The viability and spatial distribution of the female and male tissue of bisporangiate cones, and their frequent occurrence in $P$. densiflora f. multicaulis, suggests a common mechanism for the production of bisporangiate structures in all seed plants. The lack of bisexual structures in gymnosperms may be principally due to selection in order to avoid inbreeding, rather than to genetic constraints. Seedlings that develop from lateral cones might suffer from genetical or physiological disorders.

The present study could provide a reference for future research on the sexual determination and relocation of strobili in Pinus. Further studies using nursery-grown trees and transcriptional analysis should perform to determine whether there are genetically different among cones from apical, lateral, and bisexual strobili (e.g., Wang et al., 2017). The differences in developmental genetics between the viable and non-viable bisexual strobili should also be investigated. In addition, this study was conducted with a focus on female strobilus, but a comparative study of the viability and activity of microsporangiate produced in male strobilus and bisexual one should be added in the future.

\section{Acknowledgements}

This study was carried out with the support of the R\&D Program for Forest Science Technology (Project No. FTIS 2020185D10-2022-AA02) provided by the Korea Forest Service (Korea Forestry Promotion Institute).

\section{References}

Aguirre A, Vallejo-Marin M, Salazar-Goroztieta L, Arias DM \& Dirzo R (2007) Variation in sexual expression in Jacaratia Mexicana (Caricaceae) in Southern Mexico: Frequency and relative seed performance of fruit-producing males. Biotropica 39: 79-86. doi:10.1111/j.1744-7429.2006.00230.x.

Bartlett AW (1913) Note on the occurrence of an abnormal bisporangiate strobilus of Larix europea, DC. Annals of Botany 27: 575-576. doi:10.1093/ oxfordjournals.aob.a089477.

Black TM (1961) Abnormalities of the reproductive system of Pinus contorta Loudon. Annals of Botany 25: 21-28.

Bramlett DL, Belcher Jr. EW, DeBarr GL, Hertel GD, Karrfalt RP, Lantz CW, Miller T, Ware KD \& Yates III HO (1977) Cone analysis of Southern Pines. A guidebook. USDA Forest Service. General Technical Report SE-13.

Caron GE \& Powell GR (1990) Morphological variation, frequency, and distribution of bisporangiate strobili in Picea mariana. Canadia Journal of Botany 68: 1826-1830. doi:10.1139/b90-237.

Caron, GE \& Powell, GR (1995) Pollen sizing in Jack Pine (Pinus banksiana Lamb.) with a hemocytometer. Silvae Genetica 44: 96-103. 
Feng X, Xue-mei Y, Yang Z \& Fu-hua F (2018) Transcriptome analysis of Pinus massoniana Lamb. microstrobili during sexual reversal. Open Life Sciences 13: 97-106. doi:10.1515/biol-20180014.

Figuerola J, Charalambidou I, Santamaria L \& Green AJ (2010) Internal dispersal of seeds by waterfowl: effect of seed size on gut passage time and germination patterns. Naturwissenschaften 97: 555-565. doi:10.1007/s00114-010-0671-1.

Flores-Renteria L, Molina-Freaner F, Whipple AV, Gehring CA \& Dominguez CA (2013) Sexual stability in the nearly dioecious Pinus johannis (Pinaceae). American Journal of Botany 100: 602612. doi:10.3732/ajb.1200068.

Flores-Renteria L, Vázquez-Lobo A, Whipple AV, Piñero D, Márquez-Guzmán J \& Domínguez CA (2011) Functional bisporangiate cones in Pinus johannis (Pinaceae): Implications for the evolution of bisexuality in seed plants. American Journal of Botany 98: 130-139. doi:10.3732/ajb.1000275.

Hwang JW \& Lee SW (1996) Genetic variation of several isoenzymes in Pinus densiflora for. multicaulis. Journal of Korean Society of Forest Science 85: 409-415.

Jackson DI \& Sweet GB (1972) Flower initiation in temperate woody plants. Horticultural Abstracts 42: 9-24.

Kang H (2007) Changes in gender expression in Korean populations of Pinus densiflora over a fiveyear period. Journal of Plant Biology 50: 181-189. doi:10.1007/BF03030628.

Kim CS, Son YG \& Bae YM (1990) Karyological and allozyme variation in Pinus densiflora for. Multicaulis Uyeki. Korean Journal of Breeding 4: 263-274.

Kim KS, Kwon HM, Tak WS \& Choi SK (1989) Studies on cone analysis and early growth of Pinus densiflora for. multicaulis Uyeki. Research Report of Institute of Forest Genetics Korea 25: 53-55.

Matziris D (2002) Short note: Hermaphroditism in black pine. Silvae Genetica 51: 130-131.

Moon TS (2010) Environmental factors affecting graft-take of Pinus densiflora for. multicaulis grafting. $\mathrm{PhD}$ thesis. College of Bioscience, Gyeongnam National University of Science and Technology.

Niu S, Yuan H, Sun X, Porth I, Li Y, El-Kassaby YA \& Li W (2016) A transcriptomics investigation into pine reproductive organ development. New Phytologist 209: 1278-1289. doi:10.1111/nph.13680.

Osborne R \& Gorelick R (2002) Sex change in cycads. Palms \& Cycads 76: 10-15.

R Core Team (2012) R: A language and environment for statistical computing. R Foundation for Statistical Computing, Vienna, Austria. http://www.R-project.org/.

Rao LN (1931) Bisporangiate cones of Pinus longifolia and Picea morinda. Journal of Indian Botanical Society 10: 3.

Rao LN (1932) Peculiar bisexual cones of Pinus longifolia. Current Science 1: 103.

Righter FI (1932) Bisexual flowers among the pines. Journal of Forestry 30: 873.

Ross SD \& Pharis RP (1987) Control of sex expression in conifers (ed. by SV Kossuth \& SD Ross) Hormonal control of tree growth 28: 37-60. Springer, Dordrecht. doi:10.1007/978-94-0171793-9_3.

Santamour FS (1959) Bisexual conelets in spruce. Morris Arboretum Bulletin 10: 10-11.

Sarvas R (1962) Investigations on the flowering and seed crop of Pinus silvestris. Communicationes Instituti Forestalis Fenniae 53: 1-198.

Silen RR (1973) First- and second-season effect on Douglas-fir cone initiation from a single shade period. Canadian Journal of Forest Research 3: 528534. doi:10.1139/x73-078.

Wakushima S, Yoshioka H \& Sakurai N (1997) Promotion of lateral female strobilus production in Pinus densiflora by cytokinin application at a specific stage. Journal of Forest Research 2: 51-57. doi:10.1007/BF02348263.

Wang $\mathrm{H}$, Matsushita $\mathrm{M}$, Tomaru N \& Nakagawa M (2017) Sex change in the subdioecious shrub Eurya japonica (Pentaphylacaceae). Ecology \& Evolution 7: 2340-2345. doi:10.1002/ece3.2745.

Wareing PF (1958) Reproductive development in Pinus sylvestris: Physiology of forest trees (ed. by KV Thimann) Ronald Press, N.Y., pp. 643-654.

Woo KS (2003) Studies on the variation of needle, cone, and seed characteristics related to the conservation of genetic resources of Pinus densiflora for. multicaulis. Journal of Korean Forestry Society 92: 8-18.

Zobel BJ (1952) Abnormal cone formation in pines. Texas Journal of Science 4: 517-520. 